\title{
Intestinal distribution and absorption of biotin in the chicken
}

\author{
BY W. L. BR Y DEN \\ Department of Animal Husbandry, University of Sydney, Camden, NSW 2570, Australia
}

(Received 3 October 1988 - Accepted 26 April 1989)

The initial distribution and absorption of biotin in chickens was studied in vivo from either changes in the composition of intestinal contents or analysis of blood draining the gut. The progressive decline in biotin concentration and flow along the small intestine demonstrated absorption throughout this organ. Quantitatively the duodenum was the most significant site of biotin absorption when crystalline biotin was included in the diet and when dietary ingredients contained highly available biotin. In contrast, when diets of low biotin availability were given the distal segments of the small intestine contributed a relatively greater amount to biotin absorption. During passage of digesta from the ileum to the caecum there was a tenfold increase in biotin concentration. About half the amount was of ileal origin with the remainder presumably resulting from microbial synthesis. About $20 \%$ of caecal biotin was in a 'free' form but the degree of absorption from the caeca was not determined. The amount of biotin disappearing from the gut of birds given maize-based diets was similar to the quantity appearing in portal blood. Biotin absorption was not detected from wheat-based diets using arteriovenous differences.

Biotin absorption: Biotin digestion: Chicken

Just a few years ago most nutritionists would have considered a biotin deficiency most unlikely. It was generally accepted that as biotin is widely distributed in feedstuffs and abundantly produced by the intestinal microflora, supply of the vitamin was sufficient to meet requirements. However, the demonstration in this laboratory (Payne et al. 1974) and in Scotland (Whitehead et al. 1976) of the central role of biotin in the aetiology of the fatty liver and kidney syndrome (FLKS) of young chickens was ample evidence that the supply of biotin is not always adequate. In many instances biotin supplementation of commercial feeds is necessary.

Despite the widespread use of supplementary biotin, deaths from FLKS still occur (Steele et al. 1980) and there is much evidence that the incidence of the condition is influenced by maternal biotin status, the major dietary constituents (fat and protein) and the environment (see Whitehead, 1977; Pearce \& Balnave, 1978; Bannister, 1979). In all these studies little attention has been paid to the metabolism of the vitamin. The first steps in determining the relation between biotin status and supply are digestion and absorption. However, there is no information on biotin absorption in the fowl and what is known in other species is fragmentary (Rose, 1980).

In the present investigation, biotin digestion and absorption were determined in growing chickens from changes in the composition of gut contents relative to an indigestible marker and by analysing blood draining the gut. The influence of different diets on these processes was examined as the availability of biotin from different feedstuffs varies widely (Frigg, 1976; Whitehead et al. 1982; Buenrostro \& Kratzer, 1984).

The opportunity was also taken to determine whether biotin in caecal contents is in a form that can be absorbed. This was considered important as high concentrations of biotin have been recorded in the caeca (Coates et al. 1968; Bauer \& Griminger, 1980); presumably the result of microbial synthesis.

A preliminary account of the work has been given (Bryden, 1985). 


\section{MATERIALS AND METHODS}

\section{Husbandry}

Chickens (1-d-old) were obtained from a commercial hatchery and placed in brooder cages. At 3 weeks of age chicks were transferred to tiered carry-on cages. The brooders and carryon cages were situated in an air-conditioned $\left(24^{\circ}\right)$ and continuously illuminated room. Food and water were provided ad lib. and, when not on experiment, birds were given proprietary rations. The compositions of the basal diets used in the experiments are given in Table 1 .

\section{Experiments}

In both experiments birds were ranked according to live weight and then randomly allotted to experimental groups so that each group contained birds with similar mean and range of live weights.

Expt 1.The experiment was designed to determine the distribution of biotin along the gut and its partition between liquid and solid phases of digesta. Male broilers, 6 weeks old, were allocated to three groups of eight and fed on diet 1 . The diet, which was given for $14 \mathrm{~d}$ before experimentation, was supplemented with biotin $(75 \mu \mathrm{g} / \mathrm{kg})$ and celite $(20 \mathrm{~g} / \mathrm{kg})$. Celite, a diatomaceous silica product (Johns-Manville Sales Corp., Lomco, California), was added to ensure adequate levels of the dietary marker, acid insoluble ash (AIA). During the last $5 \mathrm{~d}$ of the feeding period CrEDTA, prepared by the method of Binnerts et al. (1968), was added to the diet $(200 \mathrm{mg} \mathrm{Cr} / \mathrm{kg} \mathrm{diet})$.

Birds were killed by an intracardiac injection of sodium pentobarbitone. The gastrointestinal tract was divided into sections by metal clips and removed. The commencement of the jejunum was taken as the entry of the bile and pancreatic ducts at the caudal end of the ascending limb of the duodenum, and the vitelline diverticulum (formerly Meckel's diverticulum; McLelland, 1979) indicated the boundary between the jejunum and ileum. Some segments were further divided into upper and lower portions (or anterior and posterior portions respectively) of equal length. The contents of each segment were expressed rapidly by gentle manipulation, pooled with the contents of the other seven birds from the same group, and a portion was centrifuged at $3500 \mathrm{~g}$ for $20 \mathrm{~min}$. The supernatant and solid fractions were stored at $-20^{\circ}$.

Pooled caecal samples were diluted with saline $(9 \cdot 0 \mathrm{~g}$ sodium chloride $/ 1 ; 1: 5, \mathrm{w} / \mathrm{v})$ to obtain a homogenous mixture. The mixture was divided into five portions and biotin was determined in each portion after the following treatments. (1) Total biotin: acid-hydrolysis followed by biotin determination (Hood, 1975); (2) free biotin: centrifugation at $3500 \mathrm{~g}$ for $20 \mathrm{~min}$ and measurement of biotin in the supernatant fraction without prior hydrolysis; (3) free, unbound biotin : as for treatment 2 , but precipitation of protein from the supernatant with zinc sulphate $(20 \mathrm{~g} / \mathrm{l})$ and sodium hydroxide $(10 \mathrm{~g} / \mathrm{l})$ before analysis; (4) free and bacterially-contained free biotin: boiled for $20 \mathrm{~min}$ before centrifugation and then determination of biotin in the supernatant fraction without previous hydrolysis; (5) free, unbound biotin and free, unbound biotin from bacterial cells: as for treatment 4 , but precipitation of proteins from the supernatant fraction with zinc sulphate $(20 \mathrm{~g} / \mathrm{l})$ and $\mathrm{NaOH}(10 \mathrm{~g} / 1)$ before analysis.

Expt 2. This experiment was undertaken to measure the quantity of biotin simultaneously disappearing from the small intestine and appearing in the portal vein of birds fed on diets differing in biotin availability. Crossbred layer strain males, 10 weeks old, were placed into individual cages and ten birds were fed on either diet 2, diet 3 or diet 4 for 3 weeks. Diet 4 was diet 3 supplemented with calcium (as calcium carbonate in lieu of maize) to the same level as diet 2. During the final $3 \mathrm{~d}$ of this period food intake and excreta output were recorded. Excreta were collected in $1 \mathrm{M}$-hydrochloric acid and after neutralization with 
Table 1. Compositions $(\mathrm{g} / \mathrm{kg})$ of basal diets

\begin{tabular}{|c|c|c|c|}
\hline \multirow[b]{2}{*}{ Ingredient } & \multicolumn{3}{|c|}{ Diet } \\
\hline & 1 & 2 & 3 \\
\hline Wheat & 748 & 792 & - \\
\hline Maize & — & - & 792 \\
\hline Wheat starch & 66 & - & - \\
\hline Meat meal & 120 & 200 & - \\
\hline Soya-bean meal & - & - & 200 \\
\hline Sodium caseinate & 60 & - & - \\
\hline DL-Methionine & 1 & 1.5 & 2 \\
\hline L-Lysine & 1 & $2 \cdot 5$ & 2 \\
\hline Vitamin-mineral premix* & 4 & 4 & 4 \\
\hline \multicolumn{4}{|l|}{ Chemical analysis, determined } \\
\hline Crude protein (nitrogen $\times 6 \cdot 25$ ) & 198 & 186 & 189 \\
\hline Calcium & 13 & 24 & 10 \\
\hline Biotin $(\mu \mathrm{g} / \mathrm{kg})$ & 74 & 101 & 151 \\
\hline
\end{tabular}

* The premix supplied $(/ \mathrm{kg}$ diet): retinol $3 \mathrm{mg}$, cholecalciferol $50 \mu \mathrm{g}, \alpha$-tocopherol $4 \mathrm{mg}$, menaphthone $5 \mathrm{mg}$, riboflavin $4 \mathrm{mg}$, pyridoxine $5 \mathrm{mg}$, nicotinic acid $20 \mathrm{mg}$, calcium pantothenate $15 \mathrm{mg}$, pteroylglutamic acid $2 \mathrm{mg}$, choline chloride $300 \mathrm{mg}$, cyanocobalamin $10 \mu \mathrm{g}$, ethoxyquin $125 \mathrm{mg}$, manganese $100 \mathrm{mg}$, zinc $70 \mathrm{mg}$, iron $20 \mathrm{mg}$, copper $4 \mathrm{mg}$, iodine $1 \mathrm{mg}$, cobalt $300 \mu \mathrm{g}$, selenium $100 \mu \mathrm{g}$, sodium chloride $2 \mathrm{~g}$.

$\mathrm{NaOH}$ were dried in a forced-draught oven at $80^{\circ}$. Celite was added to the diets $(20 \mathrm{~g} / \mathrm{kg})$ at the expense of wheat or maize.

Five birds from each dietary group were sampled under anaesthesia, and in order to minimize possible effects of diurnal variation of biotin concentrations, samples were collected between 09.00 and 14.00 hours. A mask was placed over the beak and nostrils of the bird and anaesthesia was induced by a mixture of oxygen, nitrous oxide and halothane (Fluothane; ICI Australia Ltd). When the respiratory pattern became regular, intubation was easy to perform by opening the beak and passing a McGill tube into the larynx by direct vision. Once the endotracheal tube was in place anaesthesia was maintained with halothane administered via an Ayre's ' $T$ ' piece using a Fluotech Mk II vapourizer (Cyprane, Keighley, Yorkshire UK). After removal of feathers, the peritoneal cavity was opened as described by Noyan (1968) and the portal vein was carefully exposed by blunt dissection to minimize bleeding and injury to surrounding tissues. Up to $2 \mathrm{ml}$ blood was removed slowly through a fine needle inserted against the blood flow of the portal vein and then a $2 \mathrm{ml}$ sample was taken from the left ventricle. Immediately after collection of blood samples packed cell volume (PCV) was determined by a capillary microhaematocrit method using a Hawksley haematocrit centrifuge. Plasma was recovered following centrifuging at $2500 \mathrm{~g}$ for $10 \mathrm{~min}$. After collection of the intestinal contents each bird was killed by an overdose of anaesthetic and portions of liver were then taken. All samples were stored at $-20^{\circ}$ and before analysis the digesta samples from the birds on each diet were pooled because of the small quantities collected from some birds.

\section{Chemical analyses}

Biotin. The radiochemical method of Hood $(1975,1977)$ was used for the determination of biotin in samples of diet, liver, excreta, digesta and plasma. Digesta samples were lyophilized, and dietary, digesta and excreta samples comminuted and all samples hydrolysed before analysis.

Dietary markers. $\mathrm{Cr}$ was determined in feed samples, total digesta and in the liquid phase 
of digesta using an atomic absorption spectrophotometer (Varian-Techtron, Melbourne). Feed and total digesta samples were ashed and diluted in $0.5 \mathrm{M}-\mathrm{HCl}$ before analysis. $\mathrm{Cr}$ was determined directly in liquid-phase samples after an appropriate dilution with $0.5 \mathrm{M}-\mathrm{HCl}$.

Acid-insoluble ash (AIA) determinations were performed by slight modification of the method described by McCarthy et al. (1974) and Vogtmann et al. (1975). A sample containing about $100 \mathrm{mg}$ AIA was placed in a weighed sintered glass crucible, dried at $104^{\circ}$ for $16 \mathrm{~h}$ and reweighed. The sample was then combusted at $500^{\circ}$ for $6 \mathrm{~h}$, boiled with $4 \mathrm{M}$ $\mathrm{HCl}$ and then thoroughly washed with water. The processes of drying $(4 \mathrm{~h})$, combustion, boiling and washing were repeated, usually twice, until the sample appeared white (Mollah, 1982). The second ashing was found necessary to remove completely all traces of carbon from the ash. The other benefit of the procedure adopted was that it did not involve the quantitative transfer of samples.

\section{Calculations}

Net absorption of a nutrient can be calculated in any section of the gut provided values for nutrient: indigestible marker ratios in both the diet and gut section are known. If food intake is recorded, flow rate and retention times of digesta can also be determined for different sections of the gut. Once equilibrium is achieved after the continuous administration of a marker (see Faichney, 1975):

$$
\text { flow rate }(\mathrm{g} / \mathrm{min})=\frac{\text { rate of administration of marker }(\mathrm{g} / \mathrm{min})}{\text { concentration of marker in digesta }(\mathrm{g} / \mathrm{g})} \text {, }
$$

and a reduction in the amount of a nutrient flowing through two successive segments of the gut can be regarded as absorption.

The retention time of digesta in segments of the intestine can then be calculated (Weston \& Hogan, 1967; Hecker \& Grovum, 1971):

$$
\text { retention time }(\mathrm{min})=\frac{\text { weight of digesta }(\mathrm{g})}{\text { flow of digesta }(\mathrm{g} / \mathrm{min})},
$$

where flow of digesta is obtained from the marker concentration in each segment.

Estimates of the net uptake or absorption of a nutrient can also be calculated from differences in concentration of the nutrient between blood supplied to the gut (arterial, A) and blood draining the gut (venous or portal, P) (Bergman, 1975; Linzell \& Annison, 1975). In the calculation of the daily uptake of biotin by the portal vein (or portal appearance) it was assumed that the concentration of the vitamin in erythrocytes was the same in arterial and portal samples; thus, uptake was calculated as (plasma P-A difference) $\times($ plasma flow), where plasma flow in the portal vein was estimated as (blood flow $) \times(100-\mathrm{PCV}) / 100$. Differences in $\mathrm{PCV}$ were used to correct the $\mathrm{P}-\mathrm{A}$ difference for possible haemodilution as blood passed through the gut (Chalmers et al. 1977). However, in most instances applying the correction made little or no difference to the result. Portal blood flow rates based on the results of Sturkie \& Abati (1975) and Purton (1975) were used, i.e. 15 and $32 \mathrm{ml} / \mathrm{min}$ per $\mathrm{kg}$ body-weight respectively.

It is accepted that estimates of absorption determined as described are net figures but this terminology does introduce a difficulty because bacterial uptake and production of biotin are hidden within the term 'net'. The signifiance of microbial metabolism of biotin and other nutrients in the avian small intestine has not been quantified but it should not be overlooked. It has been established that dietary composition has a profound effect on the colonization by bacteria of the intestinal surfaces of chickens (Salanitro et al. 1978). 


\section{RESULTS}

Expt 1. It was hoped that the use of both solid (AIA)-phase and liquid (CrEDTA)-phase markers would allow a comparison of the flow and absorption of biotin from the different digesta phases. Unfortunately, this was not possible because $\mathrm{Cr}$ was not distributed uniformly between the phases in the small intestine. Nevertheless, the ratio, CrEDTA:AIA in total digesta from segments of the small intestine and rectum, when divided by the marker ratio in the feed, differed only slightly from unity (range $0.94-1.05$ ). Thus, retention time of both markers was similar throughout these segments of the gastrointestinal tract which suggests that results are equally valid when calculated from either marker. However, it is worth noting that the digesta: feed marker values in the gizzard and caeca differed markedly from unity. In the gizzard the ratio was less than 0.88 , indicating a greater retention of $\mathrm{AlA}$ in this segment, but the increase in the ratio above 2.17 in the caeca indicated a greater retention of CrEDTA.

The mean concentration and flow of biotin, calculated using AIA, in different segments of the gastrointestinal tract are shown in Table 2. The difference between the daily intake of biotin and the flow of the vitamin in the duodenum indicated rapid absorption and presumably reflected the rapid uptake of the supplementary dietary biotin. The decrease in absorption between the distal portions of the small intestine appears to result from lower digestibility of unabsorbed biotin in these segments as the digesta retention times or time available for absorption were similar. In fact, the proportion of biotin in the liquid phase of digesta decreased distally and presumably the amount of biotin in this phase reflects the extent of digestion. The pattern of decreasing biotin flow along the small intestine indicated a net absorption of $11.8 \mu \mathrm{g} / \mathrm{d}$.

The increased concentration and flow of biotin in the rectum resulted from a net input of biotin into this segment of the gut. The source of the additional biotin is most likely the caeca where there was a tenfold increase in the concentration of the vitamin during the passage of digesta from the ileum to the caeca. Concomitant with the increase in caecal content of biotin was a fivefold increase in the concentration of CrEDTA in this organ.

The distribution of biotin in the different fractions of digesta collected from the caeca is given in Table 3. Of the total, $40 \%$ was found in the supernatant fraction and of this 'free' biotin approximately half was bound to protein. Boiling the caecal contents released a further $80 \mathrm{ng}$ biotin/g into the supernatant fraction and this amount was most likely of microbial origin as boiling is known to release the 'free' biotin contained within bacterial cells (Piffeteau et al. 1982). The remaining $46 \%$ of total biotin was firmly bound either to food residues or within bacterial cells.

Expt 2. Daily biotin intake, intestinal disappearance, $\mathrm{P}-\mathrm{A}$ difference, portal appearance, daily excretion and liver biotin concentrations are shown in Table 4 . Birds ingesting the maize-based diet 3 absorbed all the biotin they consumed, in contrast to only $20 \%$ intestinal disapperance of biotin intake in birds fed on the wheat-based diet 2 . The addition of $\mathrm{Ca}$ to the maize diet substantially reduced intestinal disappearance of the vitamin (see also Fig. 1). Interestingly, the birds fed on both maize-based diets excreted much greater quantities of biotin than they consumed, whereas the birds fed on the wheat diet consumed and excreted the same amount.

The difference due to diet in plasma biotin concentrations reflected the amount of biotin disappearing from the gut and the portal uptake of the vitamin. However, probably due to the small amount of biotin absorbed in birds fed on the wheat diet 2, it was not possible to detect the amount by using $\mathrm{P}-\mathrm{A}$ differences. Moreover, the effect of assuming different portal blood flows on the magnitude of portal uptake of biotin is demonstrated in this experiment. Obviously, uptake is proportional to blood flow and it does appear from the 
Table 2. Expt 1. Distribution and absorption of biotin from the gastrointestinal tract of chickens and retention time of digesta in gut segments

(Mean values with their standard errors; determinations on three pooled samples)

\begin{tabular}{|c|c|c|c|c|c|c|c|c|c|c|c|c|}
\hline & \multicolumn{2}{|c|}{ Duodenum } & \multicolumn{2}{|c|}{ Jejunum } & \multicolumn{2}{|c|}{ Upper ileum } & \multicolumn{2}{|c|}{ Lower ileum } & \multicolumn{2}{|c|}{ Rectum } & \multicolumn{2}{|c|}{ Caecum } \\
\hline & Mean & $\mathrm{SE}$ & Mean & $\mathrm{SE}$ & Mean & SE & Mean & $\mathrm{SE}$ & Mean & SE & Mean & $\mathrm{SE}$ \\
\hline $\begin{array}{l}\text { Biotin } \\
\text { (ng/g DM) }\end{array}$ & 575 & 58 & 420 & 14 & 352 & 19 & 187 & 32 & 377 & 96 & 2110 & 72 \\
\hline $\begin{array}{l}\text { Biotin flow } \\
(\mu \mathrm{g} / \mathrm{d})\end{array}$ & $14 \cdot 23$ & $4 \cdot 5$ & $11 \cdot 26$ & $0 \cdot 2$ & $9 \cdot 33$ & $2 \cdot 8$ & $7 \cdot 79$ & $3 \cdot 2$ & $10 \cdot 09$ & $4 \cdot 0$ & - & \\
\hline $\begin{array}{l}\text { Biotin } \\
\text { absorption }(\mu \mathrm{g} / \mathrm{d})\end{array}$ & $5 \cdot 36^{*}$ & $0 \cdot 78$ & $2 \cdot 97$ & 0.11 & 1.93 & 0.09 & $1 \cdot 54$ & 0.09 & $-2 \cdot 30$ & $0 \cdot 36$ & - & \\
\hline $\begin{array}{l}\text { Partition of } \\
\text { biotin in digesta } \dagger\end{array}$ & 1.05 & 0.07 & $0 \cdot 38$ & 0.04 & 0.18 & 0.06 & 0.11 & 0.03 & 0.43 & 0.06 & 0.66 & 0.05 \\
\hline $\begin{array}{l}\text { Retention time } \\
\text { (min) }\end{array}$ & 8.5 & $1 \cdot 1$ & $42 \cdot 1$ & $3 \cdot 8$ & $46 \cdot 0$ & $1 \cdot 4$ & $45 \cdot 0$ & $1 \cdot 4$ & $51 \cdot 6$ & $5 \cdot 4$ & - & \\
\hline
\end{tabular}

DM, dry matter.

* Mean daily intake of biotin $19.59 \mu \mathrm{g} / \mathrm{d}$.

$\dagger$ Ratio of biotin in liquid: solid phase of digesta.

Table 3. Expt 1. Biotin distribution in caecal contents of chickens

(Mean values with their standard errors; determinations on three pooled samples)

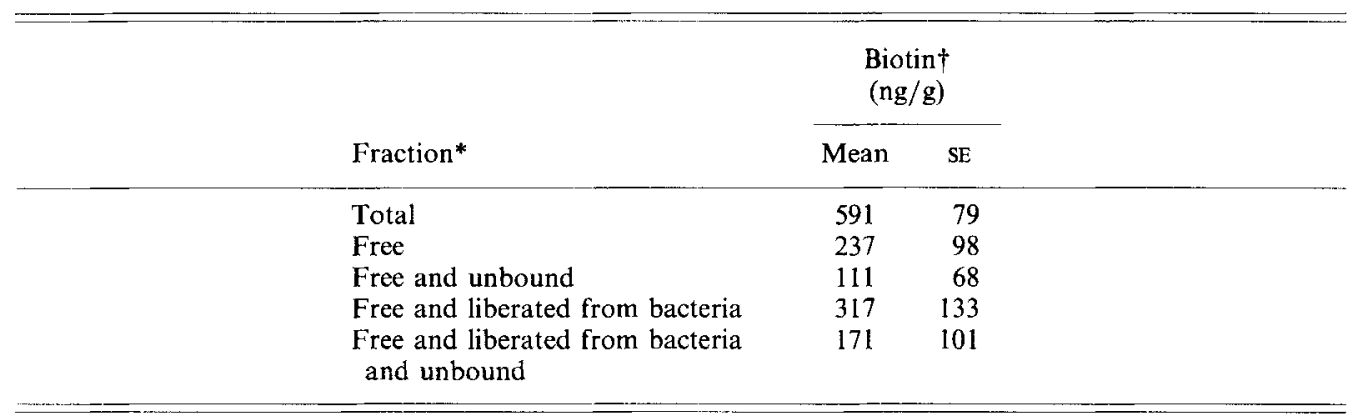

* For details of treatments, see p. 390.

$\dagger$ Calculated on a wet weight basis (i.e. $28 \mathrm{~g}$ dry matter $/ \mathrm{kg}$ ).

values that a portal flow of $15 \mathrm{ml} / \mathrm{min}$ per $\mathrm{kg}$ body-weight (Sturkie \& Abati, 1975) is the better estimate for the present experiment.

Despite the large differences in circulating levels of the vitamin in birds fed on the three diets no difference in hepatic concentration of biotin was found.

\section{DISCUSSION}

The technique of calculating apparent appearance or disappearance of digesta components using the concentration of a continuously administered indigestible marker is well established (Faichney, 1975; Hurwitz, 1976). However, no marker presently available satisfies all the criteria desired in an ideal marker and this was evident in the present study (Expt 1) where CrEDTA did not associate exclusively with the liquid phase. This aspect of the behaviour of CrEDTA has been demonstrated previously (Warner, 1969). Nevertheless, 
Table 4. Expt 2. Amounts of biotin disappearing from the small intestine, appearing in portal blood and being excreted in birds fed on three different diets

(Mean values with their standard errors; five birds per group)

\begin{tabular}{|c|c|c|c|c|c|c|}
\hline & \multicolumn{2}{|c|}{$\begin{array}{l}\text { Wheat and } \\
\text { meat meal }\end{array}$} & \multicolumn{2}{|c|}{$\begin{array}{l}\text { Maize and } \\
\text { soya-bean }\end{array}$} & \multicolumn{2}{|c|}{$\begin{array}{l}\text { Maize and soya- } \\
\text { bean + calcium }\end{array}$} \\
\hline & Mean & SE & Mean & SE & Mean & SE \\
\hline Biotin intake $(\mu \mathrm{g} / \mathrm{d})$ & 9.80 & $1 \cdot 37$ & $15 \cdot 25$ & $2 \cdot 49$ & $14 \cdot 04$ & 1.83 \\
\hline $\begin{array}{l}\text { Intestinal } \\
\text { disappearance* }(\mu \mathrm{g} / \mathrm{d})\end{array}$ & \multicolumn{2}{|c|}{$2 \cdot 01$} & \multicolumn{2}{|c|}{16.92} & \multicolumn{2}{|c|}{8.99} \\
\hline Excreta output $(\mu \mathrm{g} / \mathrm{d})$ & $10 \cdot 01$ & $3 \cdot 61$ & $27 \cdot 30$ & $6 \cdot 90$ & $18 \cdot 94$ & $8 \cdot 16$ \\
\hline \multicolumn{7}{|l|}{ Plasma biotin $(\mathrm{ng} / \mathrm{ml})$} \\
\hline Portal & 1.69 & $0 \cdot 16$ & $7 \cdot 01$ & $1 \cdot 01$ & 3.75 & 0.92 \\
\hline Arterial & 1.72 & 0.09 & $6 \cdot 14$ & 0.77 & $3 \cdot 21$ & 0.87 \\
\hline Difference & -0.03 & $0 \cdot 11$ & 0.87 & 0.29 & 0.54 & $0 \cdot 20$ \\
\hline \multicolumn{7}{|l|}{ Portal appearance $\dagger(\mu \mathrm{g} / \mathrm{d})$} \\
\hline 15 & \multirow{2}{*}{\multicolumn{2}{|c|}{ - }} & \multirow{2}{*}{\multicolumn{2}{|c|}{$\begin{array}{l}20 \cdot 04 \\
42 \cdot 75\end{array}$}} & \multirow{2}{*}{\multicolumn{2}{|c|}{$\begin{array}{l}10 \cdot 76 \\
22 \cdot 96\end{array}$}} \\
\hline 32 & & & & & & \\
\hline Liver biotin $(\mu \mathrm{g} / \mathrm{g}$ liver $)$ & $0 \cdot 71$ & 0.06 & $0 \cdot 88$ & $0 \cdot 12$ & 0.76 & 0.08 \\
\hline
\end{tabular}

* Estimated after pooling samples from all birds.

$\uparrow$ Calculated assuming portal blood flow of either 15 (Sturkie \& Abati, 1975) or 32 (Purton, 1975) $\mathrm{ml} / \mathrm{min}$ per $\mathrm{kg}$ body-weight.

Faichney (1980) has shown that imperfect markers may still be used providing conditions in the gut approximate a steady-state. The administration of the marker with the feed for at least $4 \mathrm{~d}$ before sampling, continuous feeding and lighting conditions, removal of food only at the time of sampling and the pooling of samples should have ensured that this condition was met.

The progressive decline of biotin flow throughout the small intestine observed in the present study demonstrated unequivocally that biotin is absorbed throughout the small intestine. The variations in the cumulative net absorption from the small intestine observed in both experiments are shown in Fig. 1. Quantitatively the duodenum was the most significant site of biotin absorption when crystalline biotin was included in the diet (Expt 1) and when dietary ingredients (maize and soya-bean) contained highly available biotin. In contrast, when diets (wheat and meat meal) of low biotin availability were given the distal segments of the small intestine contributed a relatively greater amount to biotin absorption. These results are similar to those published recently from this laboratory for pyridoxine absorption in the chicken (Heard \& Annison, 1986).

It was not possible to determine the extent of biotin absorption from the hind-gut because of the net inflow of biotin into both the caecum and rectum. The accumulation of the liquid-phase marker, CrEDTA, in the caeca suggests that perhaps half of the biotin in this organ is of ileal origin. Much of this biotin may come from undigested dietary components as the more soluble fractions of the diet are known to accumulate in the caecum (McNab, 1973). Moreover as there is a back flow of urine into this organ (Barnes, 1972) it is possible that some of the biotin in the caecum is of urinary origin. Fractionation of the caecal contents did show that approximately $20 \%$ of biotin in the caecum is unbound and in the liquid phase, and presumably in a form that can be absorbed. However, it may be concluded from the germ-free chick studies of Coates et al. (1968) that caecal biotin is not absorbed in the chicken, although recent studies with pigs (Barth et al. 1986) and rats (Bowman \& Rosenberg, 1987) have demonstrated biotin absorption from the mammalian 


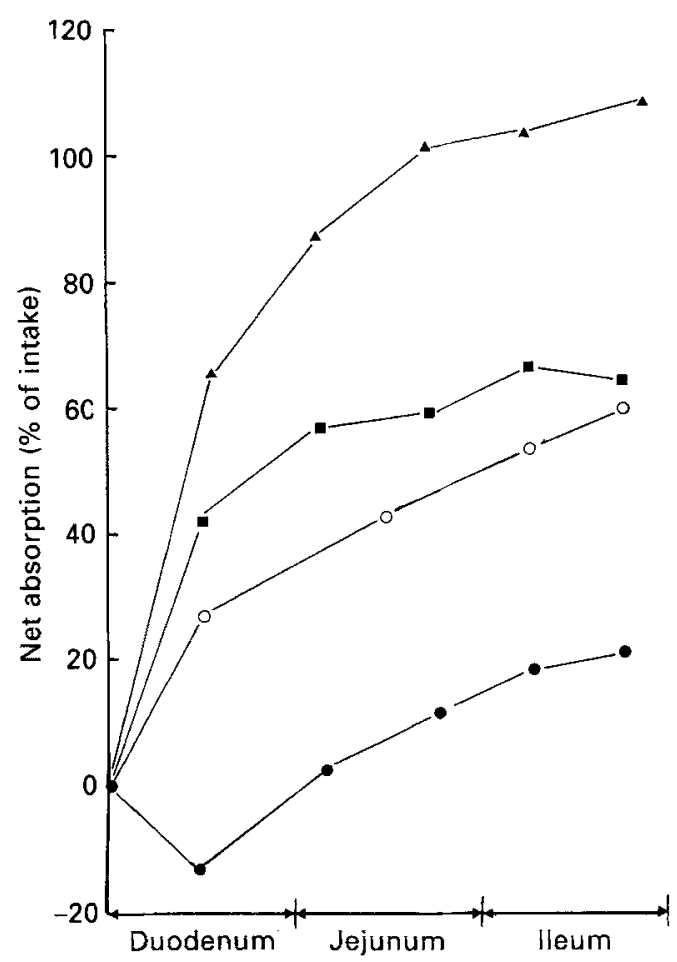

Fig. 1. Cumulative net biotin absorption by chickens from diets given in Expt $1:(0)$, wheat and meat meal +75 $\mu \mathrm{g}$ biotin/kg and Expt 2:( $)$, wheat and meat meal; $(\boldsymbol{\square})$, maize and soya-bean + calcium; ( $\boldsymbol{\Delta})$, maize and soyabean.

hind-gut. Nevertheless, caecal biotin may become available to the bird if coprophagia occurs. Indeed, Whitehead \& Bannister (1980) have estimated that broiler chickens can meet approximately $10 \%$ of their biotin requirement by ingestion of biotin in excreta. Alternatively, biotin in the caeca may move into the small intestine by retrograde movements of the intestinal tract (Nechay et al. 1968; Sklan et al. 1978) and be subsequently absorbed.

Microbial synthesis also contributes to the biotin concentration in the caecum and this would be reflected in the quantities of biotin excreted. The amount of vitamin excreted varied when different diets were given. This could result from different substrates being available for microbial metabolism or be a function of the amount of biotin remaining in undigested food residues. Biotin concentration in the growth medium controls microbial biosynthesis of biotin (McCormick, 1975; Campbell et al. 1978) and the incomplete digestion of biotin in wheat-based diets may result in the repression of biotin synthesis in the hind-gut with a corresponding decrease in the excretion of the vitamin when compared with the quantities excreted by birds fed on maize-based diets.

The failure to detect biotin absorption from the wheat and meat meal diet using arteriovenous differences is most likely the consequence of the small amounts of the vitamin being absorbed from this diet and the limitations of the method. In the present study birds were anaesthetized and, although anaesthesia is likely to affect blood flow, Bloxham (1971) found that halothane is the anaesthetic of choice in this kind of study. Accurate blood-flow measurement is necessary for the estimate of the rates of addition of a nutrient to the portal circulation. In the present study extrapolations have been made from published values for 
portal blood flow (Purton, 1975; Sturkie \& Abati, 1975), so the results derived should be treated with caution. A difficulty of deriving portal blood flow in birds is the variable contribution of the coccygeomesenteric vein to total portal flow. The validity of small $\mathbf{P}-\mathbf{A}$ differences also depends on the procedure of blood sampling, and ideally arterial and venous blood should be obtained simultaneously. This was impracticable in the present study. However, as the $\mathrm{P}-\mathrm{A}$ difference was about $15 \%$ of the arterial concentration in birds fed on the maize-based diets, this would indicate the values obtained are reliable (Barry, 1964). Using this technique it was possible to show that the amount of biotin disappearing from the gut of birds fed on the maize-based diets was similar to the amount consumed and the quantity appearing in portal blood. This agrees with the very high availability of biotin from these dietary ingredients (Frigg, 1976). Addition of $\mathrm{Ca}$ to the diet reduced the relative amounts and suggests a possible role for this mineral in the intestinal metabolism of biotin.

The results of the present study show that biotin is absorbed throughout the small intestine of the chicken and the pattern of digestion and absorption is significantly influenced by dietary composition. Moreover, further studies are required to determine the mechanism and kinetics of biotin absorption in the fowl and the extent of absorption of biotin analogues. The contribution of enterohepatic circulation and caecal biotin metabolism to the biotin economy of the bird awaits quantification.

This study was made possible by the support of The Council of Egg Marketing Authorities of Australia and the Poultry Husbandry Research Foundation within the University of Sydney. The author has been greatly helped by the efficient technical assistance of Ms Christine Murray, Ms Janene DeHon and Ms Joy Gill and discussions with Dr G. S. Heard. Dr R. L. Hood, CSIRO Division of Food Research, North Ryde, NSW provided invaluable assistance in setting up the biotin assays.

\section{REFERENCES}

Bannister, D. W. (1979). Recent advances in avian biochemistry: the fatty liver and kidney syndrome. International Journal of Biochemistry 10, 193-199.

Barnes, E. M. (1972). The avian intestinal flora with particular reference to the possible ecological significance of the ceca. American Journal of Clinical Nutrition 25, 1475-1479.

Barry, J. M. (1964). A quantitative balance between substrates and metabolic products of the mammary gland. Biological Reviews 39, 194-213.

Barth, C. A., Frigg, M. \& Hagemeister, H. (1986). Biotin absorption from the hindgut of the pig. Journal of Animal Physiology and Animal Nutrition 55, 128-134.

Bauer, K. D. \& Griminger, P. (1980). Effect of dietary carbohydrates and biotin level on cecal size and biotin concentration of growing chickens. Poultry Science 59, 1493-1498.

Bergman, E. N. (1975). Production and utilization of metabolites by the alimentary tract as measured in portal and hepatic blood. In Digestion and Metabolism in the Ruminant, pp. 292-305. [I. W. McDonald and A. C. I. Warner, editors]. Armidale: University of New England Publishing Unit.

Binnerts, W. T., Van Klooster, A. T. \& Frens, A. M. (1968). Soluble chromium indicator measured by atomic absorption in digestion experiments. Veterinary Record 82, 470.

Bloxham, D. L. (1971). Nutrition aspects of amino acid metabolism. 1. A rat liver perfusion method for the study of amino acid metabolism. British Journal of Nutrition 26, 393-422.

Bowman, B. B. \& Rosenberg, I. H. (1987). Biotin absorption by distal rat intestine. Journal of Nutrition 117, 2121-2126.

Bryden, W. L. (1985). Intestinal distribution of biotin in the chicken. XIIIth International Congress of Nutrition, p. 52, Abstract. London: John Libbey.

Buenrostro, J. L. \& Kratzer, F. H. (1984). Use of plasma and egg yolk biotin of White Leghorn hens to assess biotin availability from feedstuffs. Poultry Science 63, 1563-1570.

Campbell, A., Campillo-Campbell, A. D. \& Barker, D. (1978). Repression of biotin biosynthesis in Escherichia coli during growth on biotin vitamers. Journal of Bacteriology 135, 90-98.

Chalmers, M. I., Grant, I., Annand, M. G. \& White, F. (1977). Free amino-nitrogen used as a monitor for the uptake and movement of amino acids in sheep. Joumal of Agricultural Science, Cambridge 89, 541-550.

Coates, M. E., Ford, J. E. \& Harrison, G. F., (1968). Intestinal synthesis of vitamins of the B complex in chicks. British Journal of Nutrition 22, 493-500. 
Faichney, G. J. (1975). The use of markers to partition digestion within the gastro-intestinal tract of ruminants. In Digestion and Metabolism in the Ruminant, pp. 277-291. [I. W. McDonald and A. C. I. Warner, editors]. Armidale: University of New England Publishing Unit.

Faichney, G. J. (1980). Measurement in the sheep of the quantity and composition of rumen digesta and of the fractional outflow rates of digesta constituents. Australian Journal of Agricultural Research 31, $1129-1137$.

Frigg, M. (1976). Bio-availability of biotin in cereals. Poultry Science 55, 2310-2318.

Heard, G. S. \& Annison, E. F. (1986). Gastrointestinal absorption of vitamin $\mathbf{B}_{6}$ in the chicken (Gallus domesticus). Journal of Nutrition 116, 107-120.

Hecker, J. F. \& Grovum, W. L. (1971). Absorption of water and electrolytes from the large intestine of sheep. Australian Journal of Biological Science 24, 365-372.

Hood, R. L. (1975). A radiochemical assay for biotin in biological materials. Journal of the Science of Food and Agriculture 26, 1847-1852.

Hood, R. L. (1977). The use of linear regression analysis in the isotope dilution assay of biotin. Analytical Biochemistry 79, 635-638.

Hurwitz, S. (1976). Absorption of calcium and other minerals. In Digestion in the Fowl, pp. 157-175. [K. N. Boorman and B. M. Freeman, editors]. Edinburgh: British Poultry Science Ltd.

Linzell, J. L. \& Annison, E. F. (1975). Methods of measuring the utilization of metabolites absorbed from the alimentary tract. In Digestion and Metabolism in the Ruminant, pp. 306-319. [I. W. McDonald and A. C. I. Warner, editors]. Armidale: University of New England Publishing Unit.

McCarthy, J.F., Aherne, F. X. \& Okai, D. B. (1974). Use of HCl-insoluble ash as an index material for determining apparent digestibility with pigs. Canadian Journal of Animal Science 54, $107-109$.

McCormick, D. B. (1975). Biotin. Nutrition Reviews 33, 97-102.

McLelland, J. (1979). Digestive system. In Form and Function in Birds, vol. 1, pp. 69-181. [A. S. King and J. McLelland, editors]. London: Academic Press.

McNab, J. C. (1973). The avian caeca : a review. World's Poultry Science Journal 29, 251-263.

Mollah, Y. (1982). Metabolizable energy of poultry diets in relation to cereal carbohydrates and their interactions. PhD Thesis, University of Sydney.

Nechay, B. R., Boyarsky, S. \& Catacutan-Labay, P. (1968). Rapid migration of urine into intestine of chickens. Comparative Biochemistry and Physiology 26, 369-370.

Noyan, A. (1968). A new method for the chronic catheterization of the hepatic portal vein in the chicken. Poultry Science 47, 1922-1925.

Payne, C. G., Gilchrist, P., Pearson, J. A. \& Hemsley, L. A. (1974). Involvement of biotin in the fatty liver and kidney syndrome of broilers. British Poultry Science 15, 489-498.

Pearce, J. \& Balnave, D. (1978). A review of biotin deficiency and the fatty liver and kidney syndrome in poultry. British Veterinary Journal 134, 598-609.

Piffeteau, A., Zamboni, M. \& Gaudry, M. (1982). Biotin transport by a biotin-deficient strain of Escherichia coli. Biochimica et Biophysica Acta 688, 29-36.

Purton, M. D. (1975). Pressure-flow parameters in the hepatic vascular bed of the domestic fowl. Comparative Biochemistry and Physiology 51A, 949-955.

Rose, R. C. (1980). Water-soluble vitamin absorption in the intestine. Annual Review of Physiology 42, $157-171$.

Salanitro, J. P., Blake, I. G., Muirhead, P. A., Maglio, M. \& Goodman, J. R. (1978). Bacteria isolated from the duodenum, ileum, and cecum of young chicks. Applied Environmental Microbiology 35, 782-790.

Sklan, D., Shachaf, B., Baron, J. \& Hurwitz, S. (1978). Retrograde movement of digesta in the duodenum of the chick: extent, frequency and nutritional implications. Journal of Nutrition 108, 1485-1490.

Steele, P., Doncan, G. \& Edgar, J. (1980). Fatty liver and kidney syndrome in biotin-supplemented broiler chickens. Proceedings of the Nutrition Society of Australia 5, 209.

Sturkie, P. D. \& Abati, A. (1975). Blood flow in mesenteric, hepatic portal and renal portal veins of chickens. Pflügers Archiv 359, 127-135.

Vogtmann, H., Pfirter, H. P. \& Parabucki, A. L. (1975). A new method of determining metabolisability of energy and digestibility of fatty acids in broiler diets. British Poultry Science 16, 531-534.

Warner, A. C. I. (1969). Binding of the ${ }^{51} \mathrm{Cr}$ complex of ethylenediamine tetracetic acid to particulate matter in the rumen. Veterinary Record 84, 441-442.

Weston, R. H. \& Hogan, J. P. (1967). The digestion of chopped and ground roughages by sheep. Australian Journal of Agricultural Research 18, 789-801.

Whitehead, C. C. (1977). The use of biotin in poultry nutrition. World's Poultry Science Journal 33, $140-154$.

Whitehead, C. C., Armstrong, J. A. \& Waddington, D. (1982). The determination of the availability to chicks of biotin in feed ingredients by a bioassay based on the response of blood pyruvate carboxylase (EC 6.4.1.1) activity. British Journal of Nutrition 48, 81-88.

Whitehead, C. C. \& Bannister, D. W. (1980). Biotin status, blood pyruvate carboxylase (EC 6.4.1 .1) activity and performance in broilers under different conditions of bird husbandry and diet processing. British Journal of Nutrition 43, 541-549.

Whitehead, C. C., Blair, R., Bannister, D. W., Evans, A. J. \& Morley-Jones, R. (1976). The involvement of biotin in preventing the fatty liver and kidney syndrome in chicks. Research in Veterinary Science 20, 180-184. 